\title{
WATERFALL METHODS FOR APPLICATION OF ACCOUNTING INFORMATION SYSTEMS IN HOTEL INCOME MANAGEMENT CASE STUDY: CITRA GRAND HOTEL KARAWANG
}

\author{
lham Kurniawan', Widya Apriliah², Dede Firmansyah Saefudin ${ }^{3}$, Yuli Komalasari ${ }^{4}$, Muhammad \\ Faittullah Akbar ${ }^{5}$, Royadi6 \\ 1,2,3,4,5,6Fakultas Teknik Dan Informatika, Universitas Bina Sarana Informatika
}

\begin{tabular}{l} 
Article Info \\
\hline Article history: \\
Received 04 May, 2021 \\
Revised 09 June, 2021 \\
Accepted 06 June, 2021 \\
\hline
\end{tabular}

\section{Keywords:}

SIA

pendapatan

sewa

waterfall

java

\begin{abstract}
The need for information systems in the business more increase as the same as technological developments in the digital era which give the impacts rapidly changes in all sectors. The accounting cycle in the company is inseparable from the existence of financial recording activities in a certain period. Thus it requires an application to provides the processing financial data or it's called accounting information system. The Grand Hotel Karawang is the focus of research on building income management accounting information system. Based on the data collection method used: observation, interviews and literature studies (library research), it can be concluded that in managing hotel rental income is still manual or not computerized so that why the research to provide solutions based on the need by designing income accounting information system using waterfall software development method, with phases including needs analysis, design, implementation of program code based on open source in the implementation of the Java programming language to make easier to implement into desktop-based applications. Testing is carried out using blackbox testing as a tool for testing each process step by step in the application that all processes are running well (valid) and can be implemented as needed.
\end{abstract}

This is an open access article under the CC BY-SA license.

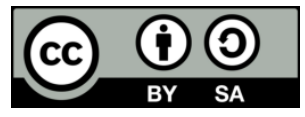

\section{Corresponding Author:}

lham Kurniawan, Dede Firmansyah Saefudin, Yuli Komalasari, Muhammad Faittullah Akbar, Royadi Fakultas Teknik dan Informatika

Universitas Bina Sarana Informatika

Email: widya.wyr@bsi.ac.id, dede.dfs@bsi.ac.id, yuli.yks@bsi.ac.id, Muhammad.mtl@bsi.ac.id, royadi.roo@bsi.ac.id

(C) The Author(s) 2021

\section{Introduction}

The tourism industry in Indonesia is growing, attracting local and international tourists to visit, both to enjoy the beautiful view, increase knowledge of historical relics, and learn about Indonesian culture that is unique and still full of traditional values [1]. The hotel industry is part of the important tourism industry in economic aspect. The hotel industry can economically make a meaningful contribution to the economy. With the sale and purchase of services, it means that the accounting process appears in it [2]. 
An accounting information system is a system has aims to collect and process data and report information related to financial transactions. The development of science and technology which is advancing rapidly gave many impacts and be a tool of information [3]. The accounting information system is a means for management to obtain information from within the company and outside the company. Information obtained from data on financial report functions in management decision making, planning, controlling, and as a source of competitive advantage [4]. Improving work systems on purchasing transactions and financial reports can be done by implementing accounting information system (AIS). A good AIS can improve the quality and cost of a product or service, increase the efficiency and effectiveness of financial report and improve the internal control structure [5].

Accounting Information Systems financial recording and reporting is very important to support the record of operating income and be implemented in Citra Grand Hotel Karawang as a support in hotel financial reports. Citra Grand Hotel Karawang is located in Badami Hamlet RT 006/ Rw 002 Margakarya Teluk Jambe Barat Karawang, which is one of the well-known hotels in the city of Karawang and belongs to the type of four-star hotel. Citra Garand Hotel Karawang provides room rental services, meeting room rentals, food sales, beverage sales, family karaoke rooms, spas and swimming pools. In order to support the needs of consumers, however, in terms of financial transaction reports, they still use manual records so that occurs error in recording financial report.

\section{Research Methods}

This research uses Waterfall model of Software Development Life Cycle (SDLC). SDLC as a framework in containing steps needed to develop a software [6].

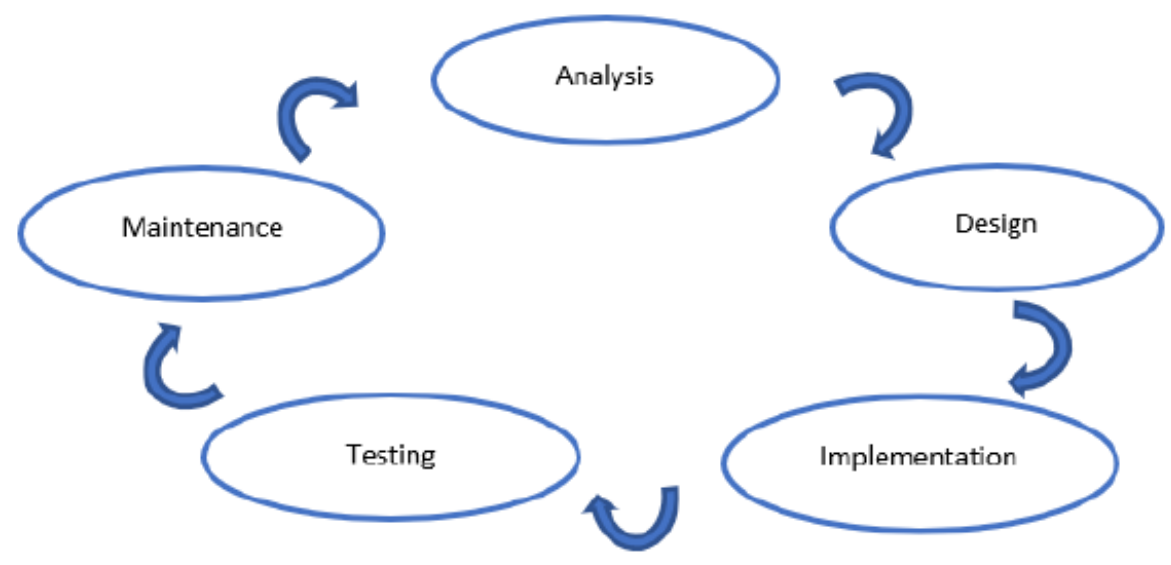

Figure 1. Tahapan metode SDLC model Waterfall

The phases of SDLC method are [6]:

1) Analysis

At this phase the researcher analyzes the structure and flow of the system in the current system at Citra Grand Hotel Karawang. The data collection method in this study applies three ways:

a. Literature study

Literature study is a method of collecting data was taken from libraries or institutions from the scientific papers, journals, books and from the internet related to this writing [7]. The purpose of this literature study is to explore and obtain complete information on the object of study.

b. Observation

Observation is a text has functions to provide information about an object or situation after a systematic investigation / research is carried out [8]. The research method used is descriptive qualitative, with a direct observation approach to obtain accurate data.

c. Interview 
An interview is a face-to-face situation between the interviewer and the respondent which is intended to gather expected information, and aims to obtain data about the respondent with minimum bias and maximum efficiency [9]. The interview process was carried out with the Marketing Staff of Citra Grand Hotel Karawang.

After the required data is collected, the next step is to process all the information obtained for the purposes of analyzing the system to be built. After finding an analysis, the next step is to observe the scope related to the implementation of the Accounting Information System for hotel income management. At this phase, the scope of the system will be determined. In this case, the limitation of the research on the system is only to cover internal transaction activities and hotel income reports.

2) Design

Design is a phase in making a flow or process and display features on the system will be built based on observations from the analysis phase before. At this phase, a design related to hotel income management modeling is carried out for admins.

\section{3) Implementation}

Implementation is the phase of writing program code to create an interface design and hotel income work process based on the design phase have been made. At the system implementation phase, coding is using the Netbean Java Desktop Application as the base for writing the program. Meanwhile, the MySQL database is used to accommodate all the information summarized in the hotel income management program. This phase is divided into several processes:

a. Design Review, it checks every Java element used, pay attention of fonts use in each article, and pay attention to the classes used in application development.

b. Selection of hardware and software resources, this process is related to the technology will be used in writing program code and installation. And of course this selection is based on the scope and other supporting resources.

4) Testing

Feature Testing is system testing to test the performance of features have been completed and look for deficiencies of features have just been implemented. At this phase, the hotel income management program has been completed will be tested in terms of the hotel income management program functionality. This phase will determine the next process. If there is an error in the system during the trial process, the next process will be returned to the previous phase. It's the system implementation phase to evaluate the failed process. On the other hand, if at the trial process without errors in the system, then the designed hotel income management program features can be implemented at Citra Grand Hotel Karawang.

5) Maintenance

After the hotel income management program can be confirmed to be published at Citra Grand Hotel Karawang, the next step is to carry out periodic maintenance of the system. The goal is to ensure features can work well and are always updated with the times.

\section{Results and Discussion}

In the results and discussion section of the application of accounting information systems in hotel income management with a case study at the Grand Citra Karawang hotel, it is necessary to carry out the phase in designing an accounting information system according to the software development method used in this study using the waterfall method. The phases of waterfall method in designing accounting information systems in this study are as follows:

\subsection{Software Requirements Analysis}

Front Office page

A1. Front Office can login

A2. Front Office can access the main menu

A3. Front Office can manage master menu

A4. Front Office can manage the master user

A5. Front Office can manage master account

A6. Front Office can manage the master room

A7. Front Office can access transactions

Jurnal Teknologi dan Open Source, Vol. 4, No. 1, June 2021: 56 - 64 
A8. Front Office can manage reservation transactions

A9. Front Office can manage invoice transactions

A10. Front Office can manage journal transactions

A11. Front Office can log out

General Manager page

B1. General Manager can login

B2. General Manager can access the main menu

B3. General Manager can access reports

B4. General Manager can log out

\subsection{Design}

After the software requirements analysis phase in design of the hotel income management accounting information system in accordance with the software requirements analysis has been described in the system requirements analysis phase above. As for the distribution of access rights in the design of hotel income management information systems, there are two access rights: access rights for the front office and general manager. At the design phase in this research using several tools: use case diagrams, activity diagrams, and database design, the research uses the ERD and LRS diagrams tools. The following is a use case diagram in designing a hotel income management accounting information system according to each access right as follows:

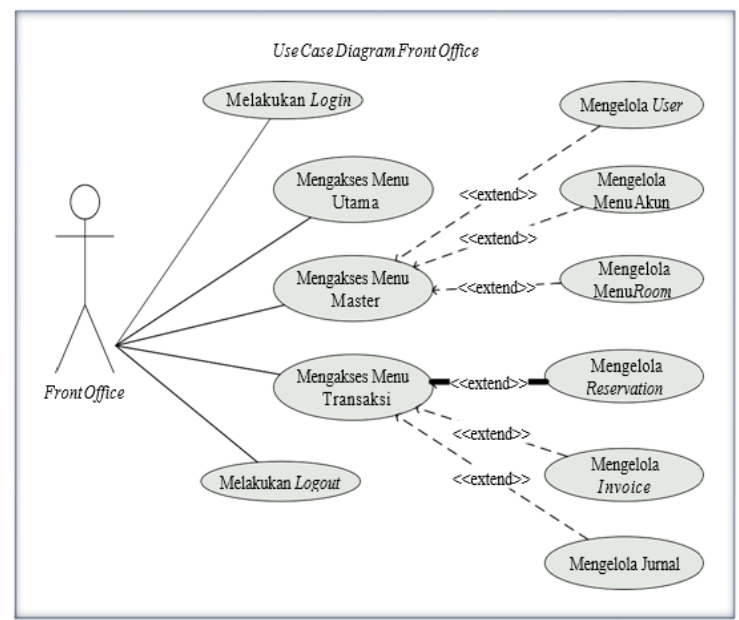

Figure 2. Diagram Use Case Hak Akses Level Front Office

The use case diagram for general manager level access rights in designing a hotel income management information system below:

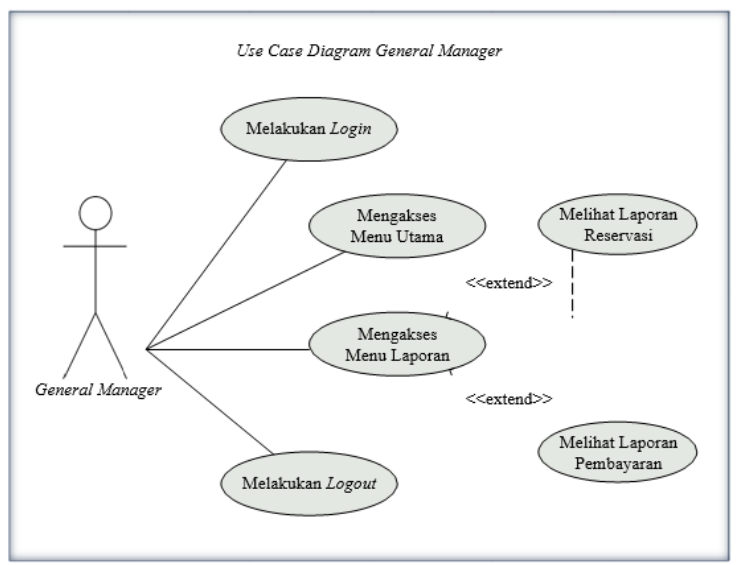

Figure 3. Diagram Use Case Hak Akses Level General Manager 
After analyzing the use case diagram, the next step is to design an accounting information system for hotel income processing. The activity diagram for front office and general amanger level access rights in the hotel income processing accounting information system is as follows:

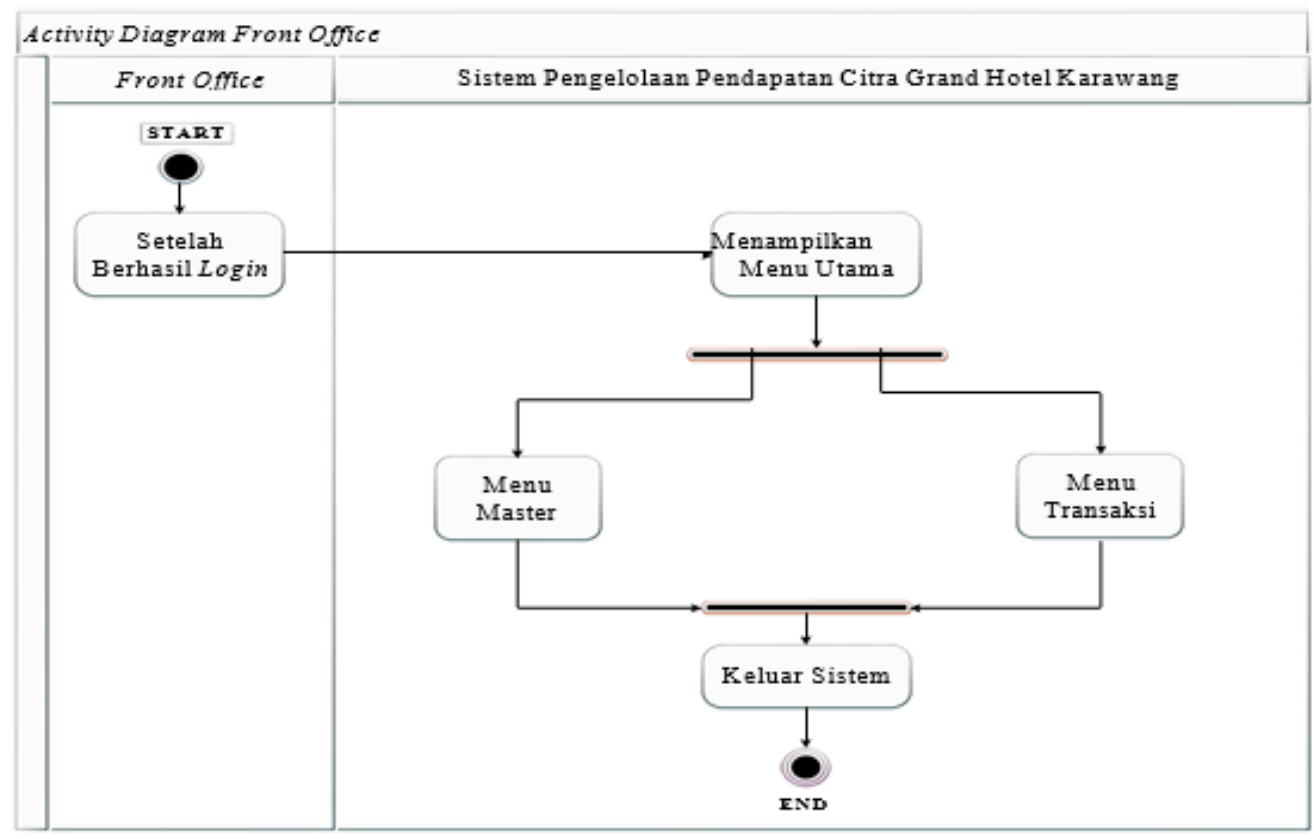

Figure 4. Diagram Activity Hak Akses Level Front Office

The following is the activity diagram for general manager level access rights in the hotel income processing accounting information system as follows:

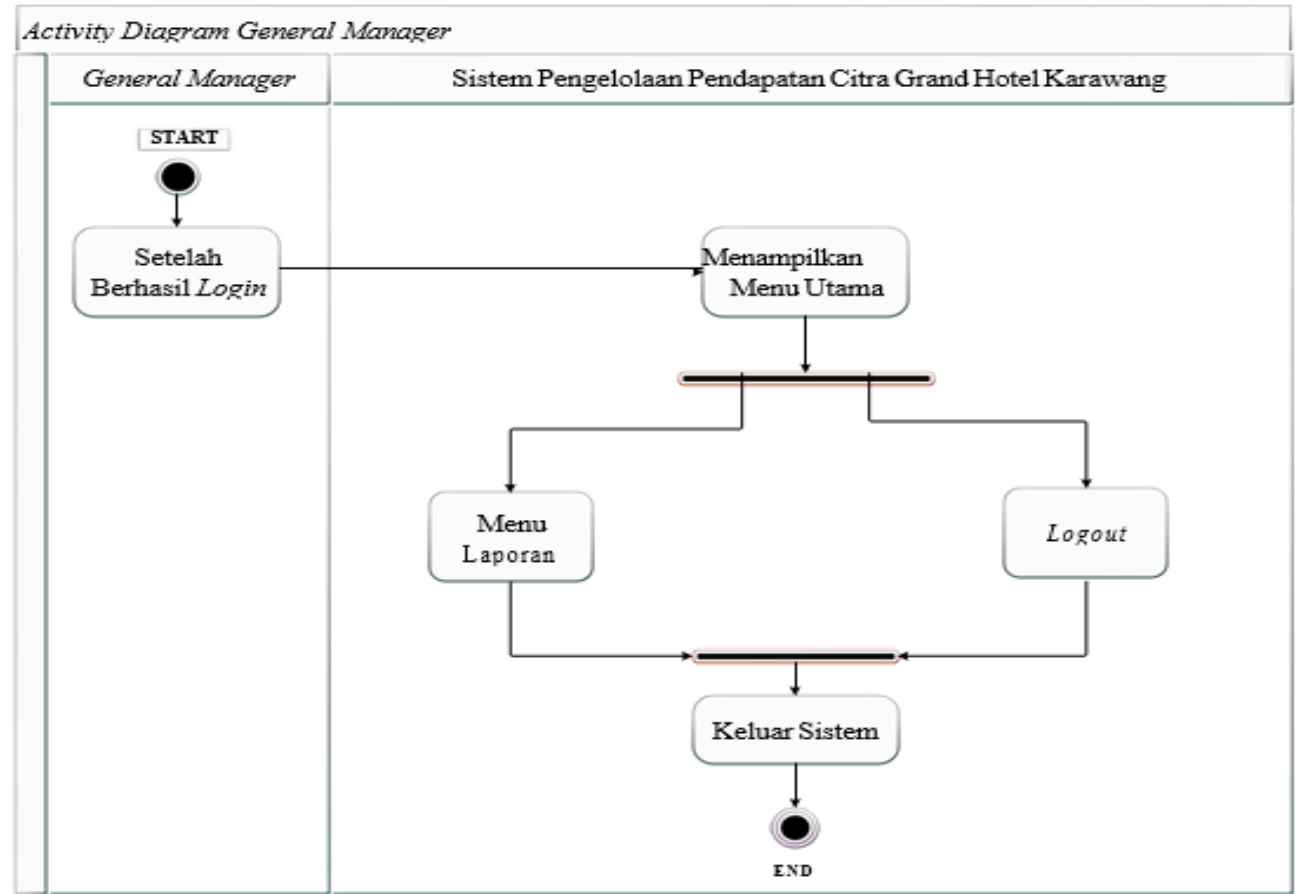

Figure 5. Diagram Activity Hak Akses Level General Manager 


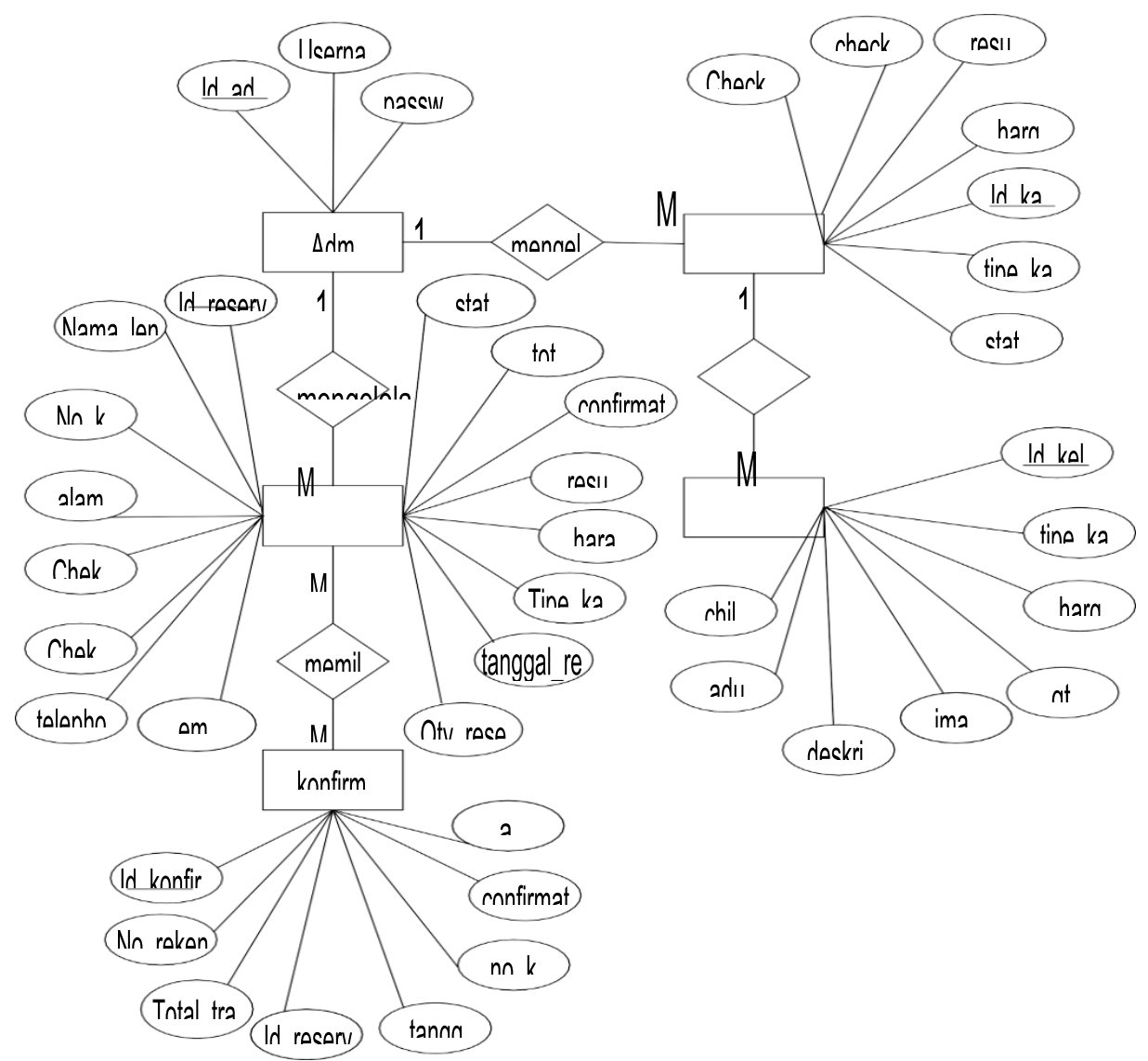

Figure 6. Diagram Entity Relation Sistem Informasi Pengolahan Pendapatan Hotel

After describing the design of the information system using use case diagrams and activity diagrams, the following is the design phase for designing income processing accounting information system database using ERD diagram tools, as follows:

The following is the database design on the hotel income processing information system using Logical Relationship Structure (LRS) diagram tools.

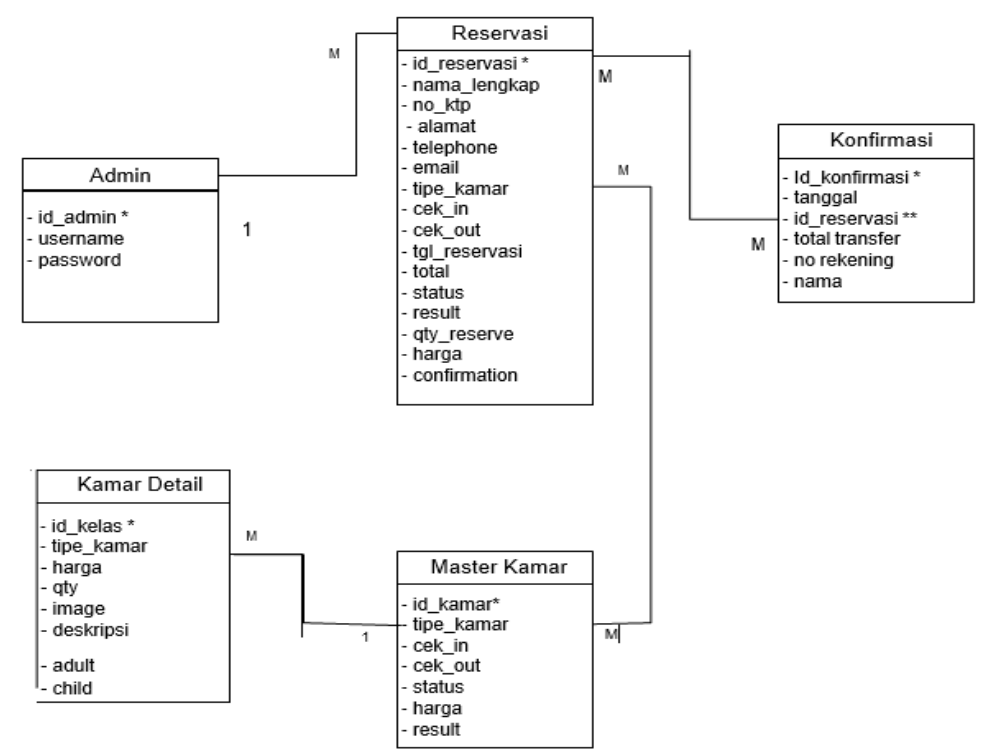

Figure 7. Diagram Logical Record Structure Sistem Informasi Pengolahan Pendapatan Hotel 
Below is a sequence diagram of the hotel revenue processing information system

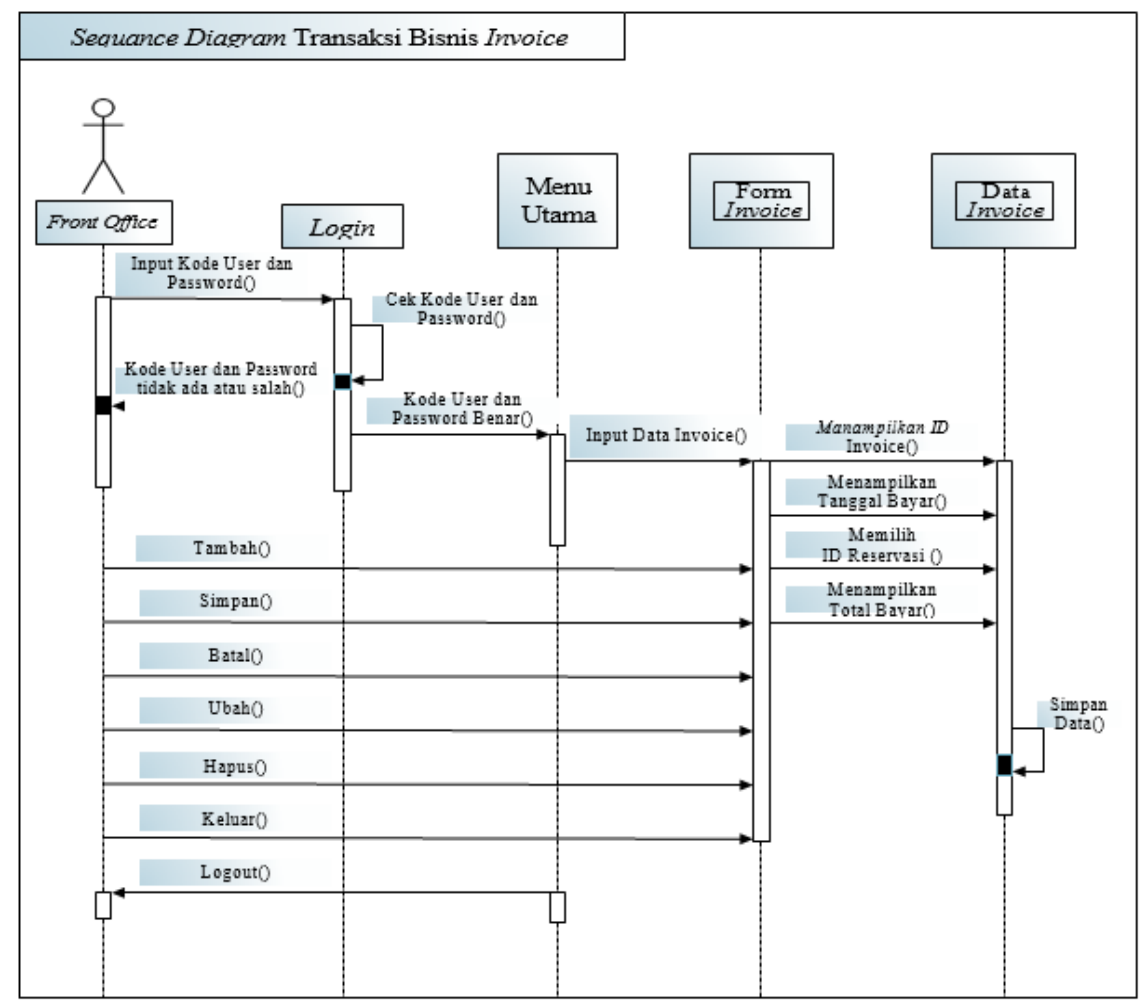

Figure 8. Diagram Sequence Sistem Informasi Pengolahan Pendapatan Hotel

\subsection{Coding}

The next phase after design phase in waterfall method is the coding. Coding phase in this research is translated into program form using a programming language. In this study, the program that will be made is desktopbased with the programming language used is Java.

\subsection{Implementation}

The following picture below is the result of the display of user interface on login menu of the Hotel income Processing Information System

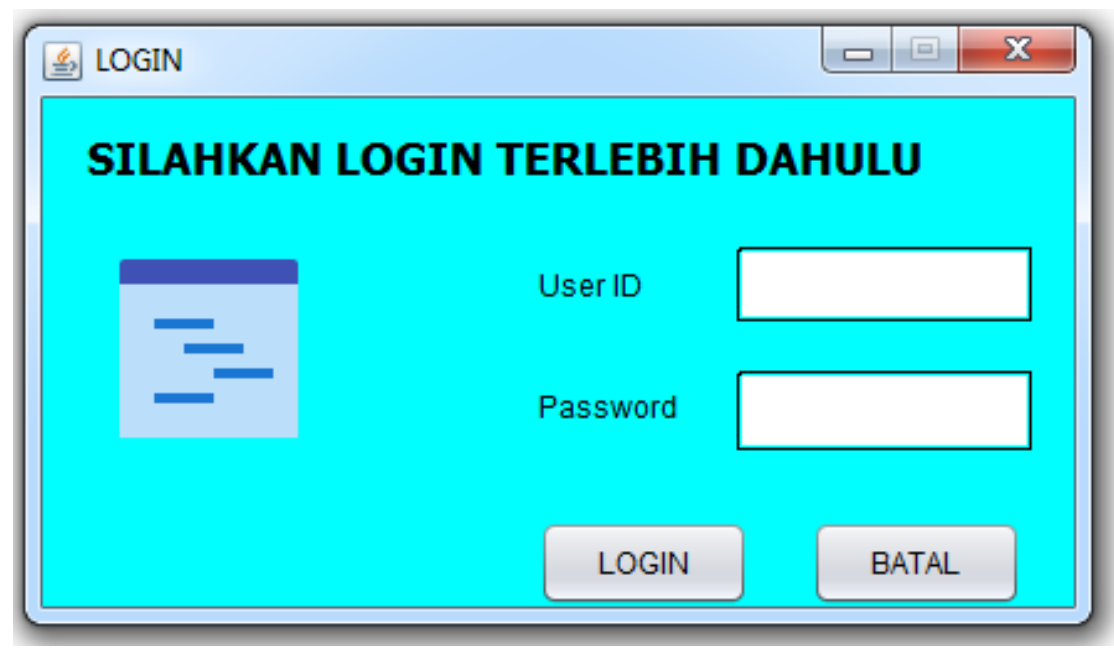

Figure 9. User Interface dari Tampilan Halaman Login pada Sistem Informasi Pengolahan Pendapatan Hotel 


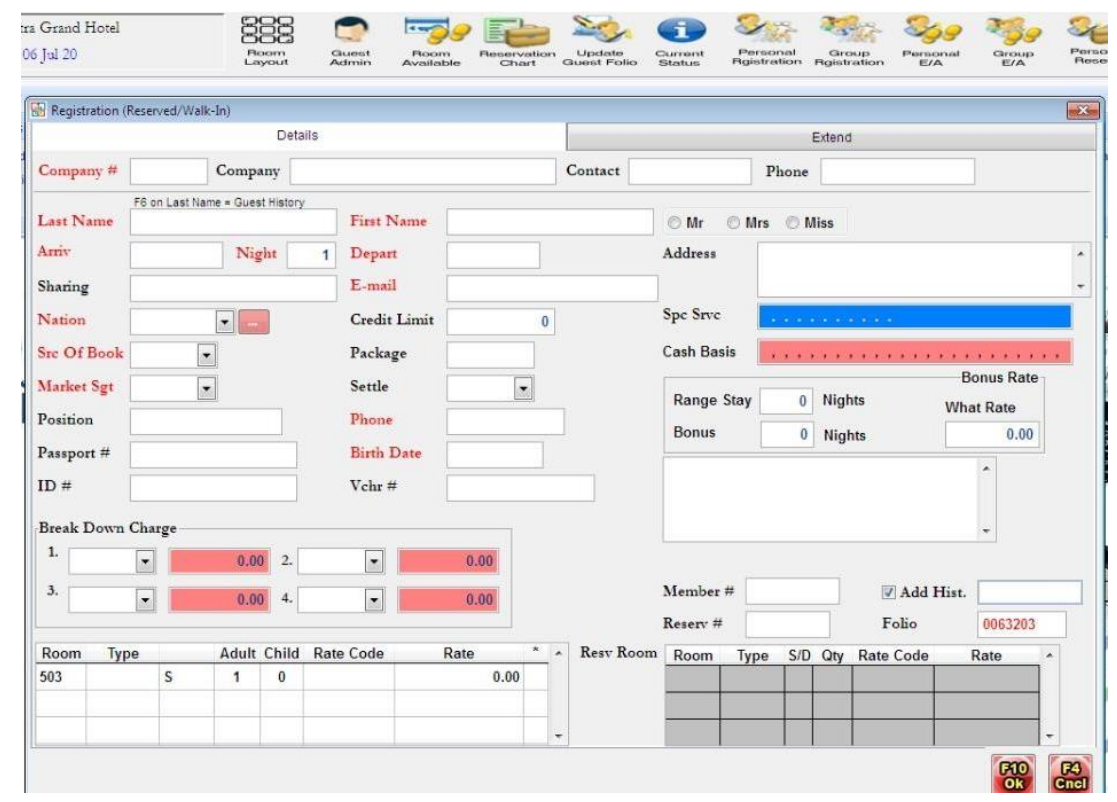

Figure 10. User Interface dari Room Reservation Form pada Sistem Informasi Pengolahan Pendapatan Hotel

\subsection{Testing}

At the testing phase using testing approach with the black box testing method focused on the functional system.

Table III.

Testing of Login Menu

\begin{tabular}{|c|c|c|c|c|c|}
\hline No & $\begin{array}{c}\text { Testing } \\
\text { Scenario }\end{array}$ & Test Case & $\begin{array}{c}\text { Expecting } \\
\text { Result }\end{array}$ & Testing Result & Conclusion \\
\hline 1 & $\begin{array}{l}\text { Klick login without } \\
\text { type data }\end{array}$ & $\begin{array}{l}\text { User code: } \\
\text { (............) } \\
\text { Password: } \\
\text { (...............) }\end{array}$ & $\begin{array}{l}\text { System denied } \\
\text { user access and } \\
\text { display } \\
\text { "unknown data" }\end{array}$ & $\begin{array}{l}\text { As } \\
\text { expectation }\end{array}$ & Valid \\
\hline 2 & $\begin{array}{l}\text { Klick login after } \\
\text { type user code } \\
\text { only, no } \\
\text { password }\end{array}$ & $\begin{array}{l}\text { User } \\
\text { code: } \\
\text { U001 } \\
\text { Password: } \\
\text { (...........) }\end{array}$ & $\begin{array}{l}\text { System denied } \\
\text { user access and } \\
\text { display } \\
\text { "unknown data" }\end{array}$ & $\begin{array}{l}\text { As } \\
\text { expectation }\end{array}$ & Valid \\
\hline 3 & $\begin{array}{l}\text { Klick login after } \\
\text { type password } \\
\text { only, no user } \\
\text { code }\end{array}$ & $\begin{array}{l}\text { Password: } \\
\text { 100U } \\
\text { User code: } \\
(\ldots \ldots \ldots \ldots . . .)\end{array}$ & $\begin{array}{l}\text { System denied } \\
\text { user access and } \\
\text { display } \\
\text { "unknown data" }\end{array}$ & $\begin{array}{l}\text { As } \\
\text { expectation }\end{array}$ & Valid \\
\hline
\end{tabular}




\begin{tabular}{|c|c|c|c|c|c|}
\hline 4 & $\begin{array}{l}\text { Input valid and } \\
\text { valid data, then } \\
\text { klick login }\end{array}$ & $\begin{array}{l}\text { User } \\
\text { code: } \\
\text { KU1 } \\
\text { (valid) } \\
\text { Password: } \\
\text { 100P } \\
\text { (unvalid) }\end{array}$ & $\begin{array}{l}\text { System denied } \\
\text { user access and } \\
\text { display } \\
\text { "unknown data" }\end{array}$ & $\begin{array}{l}\text { As } \\
\text { expectation }\end{array}$ & Valid \\
\hline 5 & $\begin{array}{l}\text { Type user code } \\
\text { and password, } \\
\text { or one of them, } \\
\text { then klick } \\
\text { cancel }\end{array}$ & $\begin{array}{l}\text { User } \\
\text { code: } \\
\text { KU1 } \\
\text { Password: } \\
\text { U001 }\end{array}$ & $\begin{array}{l}\text { No display input } \\
\text { data }\end{array}$ & $\begin{array}{l}\text { As } \\
\text { expectation }\end{array}$ & Valid \\
\hline 6 & $\begin{array}{l}\text { Input valid data, } \\
\text { then klick login }\end{array}$ & $\begin{array}{l}\text { User } \\
\text { Code: } \\
\text { KU1 } \\
\text { (valid) } \\
\text { Password: } \\
11111 \\
\text { (valid) }\end{array}$ & $\begin{array}{l}\text { System accepted } \\
\text { login access and } \\
\text { will display } \\
\text { "Welcome", then } \\
\text { it will display } \\
\text { main menu. }\end{array}$ & $\begin{array}{l}\text { As } \\
\text { expectation }\end{array}$ & Valid \\
\hline
\end{tabular}

\section{Conclusion}

Based on the results of the analysis, design, implementation and testing carried out on the features of the hotel income management program, it can be concluded that:

1) A computerized system can get results to make reports on time without re-record and can be printed. It is one of the most precise and accurate data from this system.

2) This application makes employees performance more efficient in terms of data input and report data than manual systems that require a storage area such as a cupboard, but in the system is now sufficient in databases and hard drives.

3) By performing system maintenance and regular data backup, this system can be used properly, thus allows the company to grow and earn increased income.

\section{References}

[1] V. P. Kaligis dan D. Maradesa, "SISTEM AKUNTANSI PENDAPATAN ATAS PENGAKUAN PENDAPATAN PADA LAPORAN KEUANGAN (STUDI KASUS PADA HOTEL SAHID KAWANUA MANADO)," J. EMBA, vol. 9, no. 1, hal. 1213-1220, 2020.

[2] E. Callestyo dan P. Adiasih, "Rancang Sistem Informasi Akuntansi Siklus Pendapatan Hotel 'X ' di Surabaya," Bus. Account. Rev., vol. 5, no. 2, hal. 769-780, 2017.

[3] B. Tambunan, F. Harahap, dan R. Dewi, "Sistem Informasi Akuntansi Pendapatan Tenaga Kerja Pada PT . Koperasi Upaya Karya Dengan Metode Cash Basis,” SENSITEK 2018, hal. 724-726, 2018.

[4] Risky, M. Kafrawi, dan A. Setiawan, "PENGARUH PENERAPAN SISTEM INFORMASI AKUNTANSI PENJUALAN DAN PEMBELIAN TERHADAP PENCAPAIAN LABA PADA PT PRAKARSA MITRA SOLUSINDO MAKASSAR,” Econ. BOSOWA J., vol. 6, no. 005, hal. 142-155, 2020.

[5] M. H. Yulianto dan D. Djuharni, "Analisis Sistem Informasi Akuntansi Pembelian Dan Penjualan Pada CV. Tri Kencana Cilegon-Banten,” J. Akunt. Kontemporer, vol. 11, no. 1, hal. 40-51, 2019.

[6] N. Cahya, A. Triayudi, dan Benrahman, "Implementasi Framework Codeigniter Pada Perancangan Program pengelolaan pendapatan hotel Interaktif Menerapkan Metode Waterfall," J. Media Inform. Budidarma, vol. 5, no. 1, hal. 273-279, 2021.

[7] Ernawati, A. Johar, dan S. Setiawan, "Implementasi Metode String Matching Untuk Pencarian Berita Utama Pada Portal Berita Berbasis Android (Studi Kasus: Harian Rakyat Bengkulu)," J. Pseudocode, vol. 6, no. 1, hal. 77-82, 2019.

[8] W. Yulia, "Peningkatan Keterampilan Menulis Teks Laporan Hasil Observasi dengan Menggunakan Metode Field," J. Diksatrasia, vol. 1, no. 2, hal. 349-357, 2017.

[9] Nanda Wafiya, N. Agitha, dan Muliadi, "Perancangan Dan Pembuatan Sistem Informasi Perpustakaan Pada SDN 26 Mataram," J. Begawe Teknol. Inf., vol. 2, no. 1, hal. 46-53, 2021. 